\title{
Doses and application methods of Azospirillum brasilense in irrigated upland rice
}

\author{
Nayara F. S. Garcia ${ }^{1}$, Orivaldo Arf ${ }^{1}$, José R. Portugal ${ }^{1}$, Amanda R. Peres ${ }^{1}$, \\ Mayara Rodrigues $^{2} \&$ Mariele de S. Penteado ${ }^{1}$ \\ ${ }^{1}$ Universidade Estadual Paulista “Júlio de Mesquita Filho”/Faculdade de Engenharia de Ilha Solteira. Ilha Solteira, SP. E-mail: nayaragarcia.agro@gmail.com \\ (Corresponding author); arf@agr.feis.unesp.br; jrp_agro@yahoo.com.br; amandarperes_agro@yahoo.com.br; mariele.souzap@gmail.com \\ ${ }^{2}$ Universidade de São Paulo/Escola Superior de Agricultura “Luiz de Queiroz”. Piracicaba, SP. E-mail: mayararodrigues.agro@gmail.com
}

\section{Key words:}

Oryza sativa L. diazotrophic cv. IAC 202 nitrogen fixation grain yield

\begin{abstract}
A B S T R A C T
The study was carried out in Selvíria-MS, in the 2011/12 and 2012/13 agricultural years, aiming to evaluate the efficiency of Azospirillum brasilense in nitrogen fixation in upland rice, as a function of doses and application methods of the inoculant containing this diazotrophic bacterium. The experimental design was randomized blocks, arranged in a $4 \mathrm{x} 4$ factorial scheme, with 4 doses of inoculant (control without inoculation, 100, 200 and $300 \mathrm{~mL}$ of the commercial product ha $\mathrm{a}^{-1}$ ) and 4 application methods (seed inoculation, application in the sowing furrow, soil spraying after sowing, and foliar spraying at the beginning of plant tillering), with 4 replicates. During the experiment, the agronomic characteristics, production components and yield of the rice crop were evaluated. It was concluded that the inoculant containing Azospirillum brasilense promotes increase (19\%) in the yield of upland rice under sprinkler irrigation when used at the dose of $200 \mathrm{~mL} \mathrm{ha}^{-1}$, regardless of the application methods.
\end{abstract}

Palavras-chave:

Oryza sativa L.

bactérias diazotróficas

cultivar IAC 202

fixação de nitrogênio

produtividade

\section{Doses e modos de aplicação de Azospirillum brasilense em arroz de terras altas irrigado}

\section{R E S U M O}

Este trabalho, desenvolvido no município de Selvíria, MS, nos anos agrícolas de 2011/12 e 2012/13 teve, como objetivo, avaliar a eficiência de Azospirillum brasilense na fixação de nitrogênio em arroz de terras altas, em função de doses e modos de aplicação do inoculante contendo a bactéria diazotrófica. Utilizou-se delineamento experimental de blocos ao acaso disposto em esquema fatorial $4 \mathrm{x} 4$ sendo 4 doses de inoculante (testemunha sem inoculação, 100, 200 e $300 \mathrm{~mL}$ do produto comercial ha ${ }^{-1}$ ) x 4 modos de aplicação (inoculação das sementes, aplicação no sulco de semeadura, pulverização do solo logo após a semeadura e pulverização foliar no início do perfilhamento das plantas) com 4 repetições. Durante a condução do experimento foram avaliados as características agronômicas, os componentes de produção e a produtividade da cultura do arroz. Conclui-se que o inoculante contendo Azospirillum brasilense promove acréscimo (19\%) na produtividade de arroz de terras altas irrigado por aspersão, quando usado na dose de $200 \mathrm{~mL} \mathrm{ha}^{-1}$, independentemente do modo de aplicação. 


\section{INTRODUCTION}

Despite the reductions in rice production and yield in the $2015 / 16$ season, compared with the previous one, respectively 14.3 and $0.6 \%$ (CONAB, 2016), the production chain of this cereal is currently one of the most important for the Brazilian agribusiness, since it is a product with high internal consumption and that represents an expressive volume of the grain production in the country (Zamberlan \& Sonaglio, 2011).

The rice plant is characterized for having high demand for nutrients and nitrogen $(\mathrm{N})$ being the main limiting factor to its yield. It is a component of the chlorophyll that increases plant leaf area and, in turn, increases the efficiency in solar radiation interception and photosynthetic rate, thus having high influence on grain yield (Fageria \& Stone, 2003). Additionally, it influences the number of panicles per area unit and of spikelets per panicle, fertility of spikelets, grain weight and panicle length (Fageria \& Barbosa Filho, 2001).

Analyzing this agricultural scene and given the importance of this nutrient, studies that evaluate $\mathrm{N}$-fixing bacteria, regarding their alternative supply of this nutrient, are an important sustainable method in agriculture (Elbeltagy et al., 2001; Guimarães et al., 2007) and can promote yield increments, which is very important because, for upland rice in the Central-West region of Brazil $\left(3,203 \mathrm{~kg} \mathrm{ha}^{-1}\right)$, for example, is relatively lower than that of the irrigated system $\left(6,798 \mathrm{~kg} \mathrm{ha}^{-1}\right)$ obtained in the south of the country (CONAB, 2016).

It is important to point out that the process of biological fixation by these bacteria excretes only part of the $\mathrm{N}$ directly fixed to the associated plant, but it is able to meet just part of the $\mathrm{N}$ requirements of the plants (Hungria et al., 2010).

The bacteria of the Azospirillum genus, also considered as plant growth-promoting bacteria (PGPB), besides promoting biological N fixation (Perrig et al., 2007), synthesize hormones such as auxin, which stimulates shoot and root growth of various grass crops, including rice (Radwan et al., 2004); however, studies involving this crop with the use of inoculants and the various forms of inoculation are still scarce.

Considering the above, this study was conceived with the objective of evaluating the influence of doses and forms of application of inoculant containing Azospirillum brasilense in upland rice under sprinkler irrigation.

\section{Material AND Methods}

The study was carried out during the agricultural years of 2011/12 and 2012/13 in an experimental area of the Faculty of Engineering - UNESP, Campus of Ilha Solteira, located in the municipality of Selvíria, MS, Brazil, at approximate coordinates of $51^{\circ} 22^{\prime} \mathrm{W}$ and $20^{\circ} \mathrm{S}$, with altitude of $340 \mathrm{~m}$.

The local soil is a clayey typic dystrophic Red Latosol (Santos et al., 2013). The mean annual rainfall is $1,370 \mathrm{~mm}$, mean annual temperature is $23.5^{\circ} \mathrm{C}$ and mean annual relative air humidity is between 70 and $80 \%$.

The climatic conditions during the experiment are shown in Figure 1.

The experimental design was randomized blocks, arranged in a $4 \times 4$ factorial scheme. The treatments consisted of the combinations of doses of inoculant containing Azospirillum brasilense (control without inoculation, 100, 200 and $300 \mathrm{~mL}$ $\mathrm{ha}^{-1}$ of the commercial product) and forms of application (seed inoculation, application in the sowing furrow, soil spraying after sowing and foliar spraying at the beginning of plant tillering), with 4 replicates. Plots comprised four $4.5-\mathrm{m}$-long rows spaced by $0.35 \mathrm{~m}$. The evaluated area consisted of the three central rows, disregarding $0.50 \mathrm{~m}$ on each side.

Before installing the experiment, in 2014, soil samples were collected in the layer of $0.00-0.20 \mathrm{~m}$ for chemical analysis and the results are presented in Table 1 .

Soil preparation was performed with chisel plow and two harrowings for leveling, the last of which one day before sowing. Sowing occurred on November 8, 2011, and on November 7, 2012, using the amount of seeds necessary to obtain 180 plants $\mathrm{m}^{-2}$ of the cultivar IAC 202 . The seeds were previously treated with fipronil $(50 \mathrm{~g}$ of a.i. $100 \mathrm{~kg}$ of

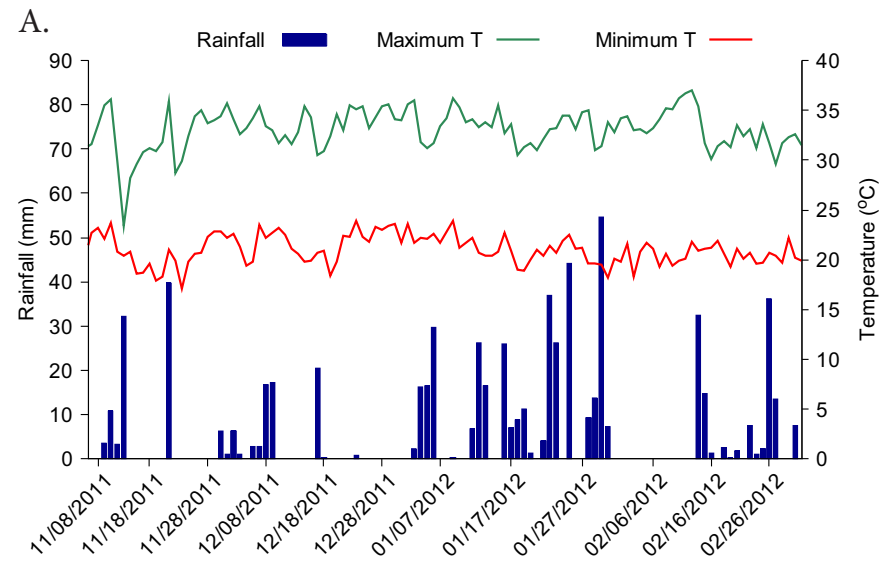

B.

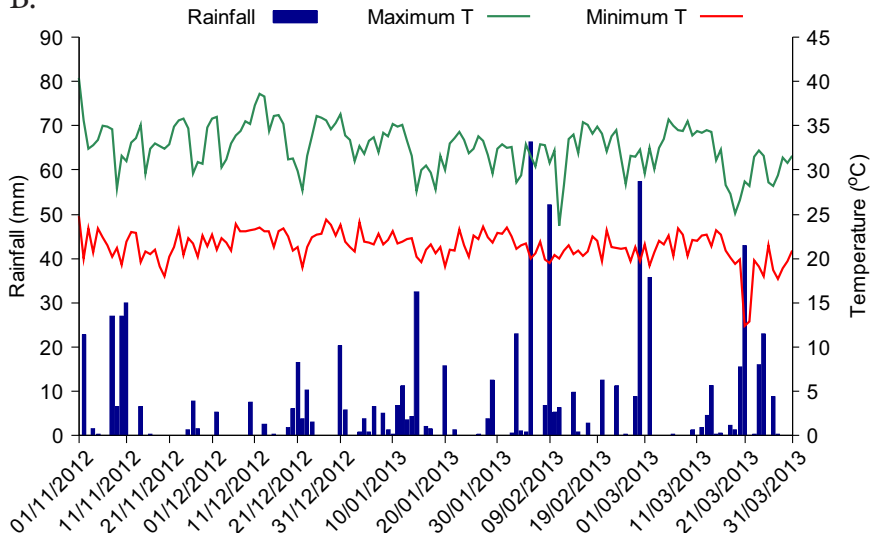

Figure 1. Values of rainfall and temperature in the experimental area in the period from sowing to harvest of rice in the agricultural years of 2011/12 (A) and 2012/13 (B)

Table 1. Results of soil chemical analysis in the layer of $0.00-0.20 \mathrm{~m}$, before experiment installation

\begin{tabular}{|c|c|c|c|c|c|c|c|c|c|}
\hline $2012 / 13$ & 11 & 21 & $\begin{array}{c}\mathrm{Ca} \mathrm{L}_{2} \\
5.2\end{array}$ & 3.0 & 15.0 & 10.0 & 19.0 & 47.0 & 59 \\
\hline
\end{tabular}


seeds $^{-1}$ ) aiming to control termites and lesser cornstalk borer (Elasmopalpus lignosellus). A seeder-fertilizer tractor was used for most treatments and a manual seeder for the treatments with application of Azospirillum brasilense in the seeds.

Inoculation was performed in the shade, just before sowing, with the Azospirillum brasilense strains $\mathrm{Ab}-\mathrm{V}_{5}$ and $\mathrm{Ab}-\mathrm{V}_{6}$. The utilized inoculant contained $2 \times 10^{8}$ viable cells per $\mathrm{mL}$ of the commercial product. The product was sprayed in the sowing furrow just before sowing using a backpack sprayer with flow rate of $200 \mathrm{~L} \mathrm{ha}^{-1}$. The application in the soil was performed one day after sowing, around $16 \mathrm{~h}$, also using a backpack sprayer with flow rate of $200 \mathrm{~L} \mathrm{ha}^{-1}$ and, immediately after, an irrigation was applied with a water depth of $10 \mathrm{~mm}$; foliar application was performed 15 days after emergence (DAE), at the beginning of plant tillering, using a manual backpack sprayer with flow rate of 200 $\mathrm{L} \mathrm{ha}^{-1}$, between 19:30 and 20:00 $\mathrm{h}$, with mild temperature and little wind for higher application efficiency and ideal conditions for the bacteria.

The mineral fertilization used in the sowing furrows was calculated according to the soil chemical characteristics taking into consideration the recommendations of Cantarella \& Furlani (1996). $250 \mathrm{~kg} \mathrm{ha}^{-1}$ of the formulation 04-30-10 were used and the top-dressing fertilization was performed at 30 DAE, using ammonium sulfate as the source. The utilized dose was $42 \mathrm{~kg} \mathrm{ha}^{-1}$ of $\mathrm{N}$, defined based on the expected yield range and the class of soil response to $\mathrm{N}$, by applying $70 \%$ of the recommendation. At first, it was expected that the other $30 \%$ were supplied by the diazotrophic bacteria; immediately after application, irrigation was performed with a water depth of approximately $10 \mathrm{~mm}$.

Water was supplied through a fixed sprinkler irrigation system with mean flow rate of $3.3 \mathrm{~mm} \mathrm{~h}^{-1}$ in the sprinklers. For water management, three crop coefficients (Kc) were used, distributed in four periods, comprehended between emergence and harvest. For the vegetative stage, the value of 0.4 was used; for the reproductive stage, two crop coefficients were used, the initial of 0.70 and the final of 1.00; and, for the maturation stage, these values were inverted, i.e., the initial of 1.00 and the final of 0.70 (Rodrigues et al., 2004).

A fungicide containing trifloxystrobin + tebuconazole (75 $+150 \mathrm{~g}$ a.i. $\mathrm{ha}^{-1}$ ) was applied for the control of upland rice diseases, such as blast and helminthosporium, in the entire experimental area at 65 and $78 \mathrm{DAE}$; the other cultivation practices were performed according to the recommendations for the crop.

At flowering, the $\mathrm{N}$ content was evaluated in the leaves, determined through the collection of the leaf blades of 20 flag leaves per plot and following the methodology of Malavolta et al. (1997); plant height ( $\mathrm{m})$, during the stage of pasty grains, at 3 random points per plot, measured as the distance between soil surface and the upper tip of the highest panicle; number of panicles per square meter, determined by the count of the number of panicles in $1.0 \mathrm{~m}$ of plant row in the evaluated area and then calculated per square meter.

In the crop maturation stage, 100-grain weight was also determined, by randomly collecting and weighing two 100 -grain samples of each plot (13\% wet basis), as well as hectoliter mass, evaluated by weighing a 0.25 -L sample of grains of each plot and then converting to $\mathrm{kg} 100 \mathrm{~L}^{-1}$ at $13 \%$ of moisture. Lastly, grain yield was determined through the weight of hulled grains, from the evaluated area of the plots, correcting moisture to $13 \%$ and converting it to $\mathrm{kg} \mathrm{ha}^{-1}$.

The results were subjected to the $\mathrm{F}$ test of the analysis of variance, comparing the means of the treatments with Azospirillum brasilense by Tukey test at 0.05 probability level for the forms of application and polynomial regression for the inoculant doses, fitting models of significant linear and quadratic equations by $\mathrm{F}$ test $(\mathrm{p}<0.01$ and $\mathrm{p}<0.05)$. The statistical analyses were performed using the program SISVAR (Ferreira, 2011).

\section{Results AND Discussion}

In the 2011/12 agricultural year, the accumulated rainfall during the crop cycle was $652 \mathrm{~mm}$ (Figure 1A), while in the second year (2012/13) it was $513 \mathrm{~mm}$ (Figure 1B), thus in agreement with the crop requirement, which is between 450 and $700 \mathrm{~mm}$ during the entire cycle. This behavior depends on the cultivar and on the soil in the cultivation area (Rodrigues et al., 2004).

In the agricultural years of 2011/12 and 2012/13, plant emergence occurred at 6 and $7 \mathrm{DAE}$ and the full rice flowering occurred at 86 and 75 DAE, respectively. The maturation allowed the harvest on February 27, 2012 (107 DAE) and on February 26, 2013 (104 DAE) in the first and second years, respectively.

The obtained results for leaf $\mathrm{N}$ content, plant height and number of panicles $\mathrm{m}^{-2}$ are presented in Table 2 .

Leaf $\mathrm{N}$ contents and the number of panicles $\mathrm{m}^{-2}$ were not influenced by the treatments of doses and forms of application of inoculant, in both seasons. $\mathrm{N}$ values in the flag leaf (leaf $\mathrm{N}$ ) remained always in the range reported by Raij et al. (2001) as adequate (27-35 $\left.\mathrm{g} \mathrm{kg}^{-1}\right)$.

Araújo et al. (2010) and Goes (2012), evaluating Azospirillum brasilense inoculation in rice seeds, also did not find difference in the number of panicles per $\mathrm{m}^{2}$, corroborating the results found in the present study.

For plant height (Table 2), there was no significant effect in the first cultivation year; however, for the agricultural year of $2012 / 13$, there was interaction between the doses and forms of application of the inoculant containing Azospirillum brasilense.

According to the follow-up analysis (Table 3) for inoculant doses in each form of application, for the applications in the soil, seed and plant, $\mathrm{PH}$ fitted to quadratic functions with maximum estimated points of 183, 135 and $158 \mathrm{~mL} \mathrm{ha}^{-1}$, respectively. For the application in the sowing furrow, the data fitted to a positive linear equation, i.e., the higher the inoculant dose, the higher the $\mathrm{PH}$ of upland rice.

As to the follow-up analysis for the forms of application at the inoculant doses, it is observed that, at the dose of 100 $\mathrm{mL} \mathrm{ha}{ }^{-1}$, the application in the sowing furrow showed lower $\mathrm{PH}$, whereas at the dose of $300 \mathrm{~mL} \mathrm{ha}^{-1}$ of inoculant the application in the soil showed higher value in comparison to the application in the seed.

According to Bottini et al. (1989), the production of phytohormones by bacteria, as in the case of inoculation with 
Table 2. Mean values of leaf nitrogen (N), plant height $(\mathrm{PH})$ and number of panicles $\mathrm{m}^{-2}$ (PAN) of upland rice as a function of doses and forms of application of inoculant containing Azospirillum brasilense during 2011/12 and 2012/13 season

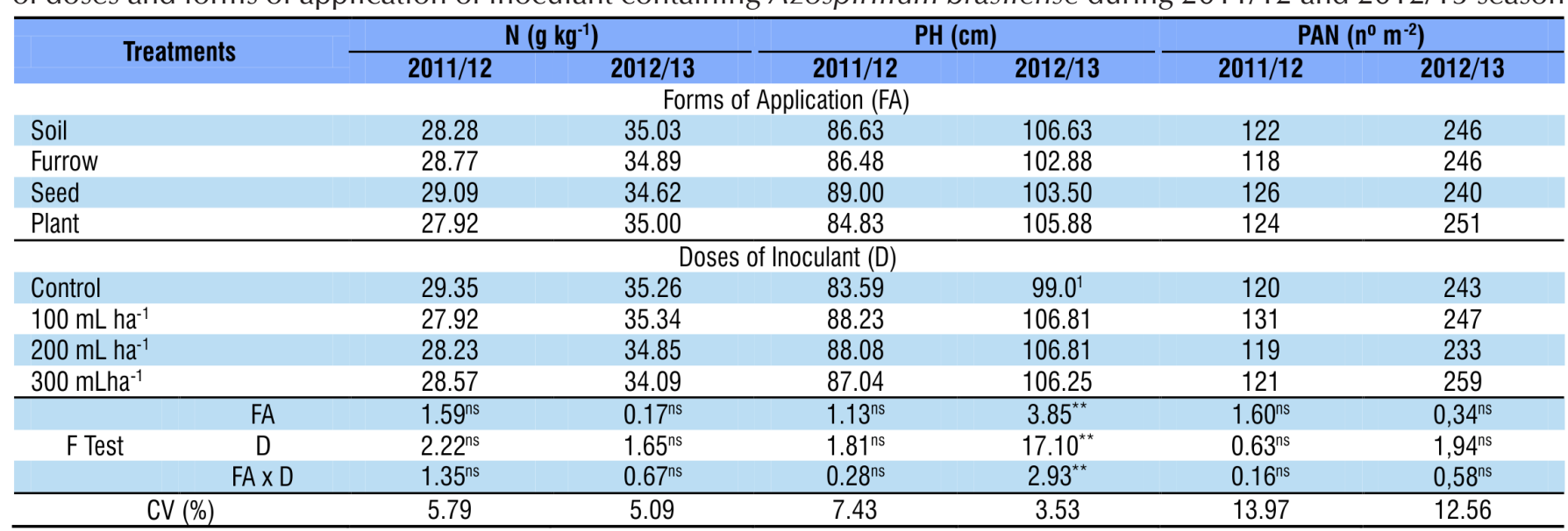

${ }^{n s}$ Not significant ${ }^{* *}$ and ${ }^{*}$ Significant at 0.01 and 0.05 probability levels, respectively

Table 3. Follow-up analysis of the interaction of inoculant doses $x$ forms of application of Azospirillum brasilense for plant height $(\mathrm{PH})$ of upland rice under sprinkler irrigation during 2012/13 season

\begin{tabular}{|c|c|c|c|c|}
\hline \multirow{3}{*}{$\begin{array}{l}\text { Forms/ } \\
\text { doses }\end{array}$} & \multicolumn{4}{|c|}{ Dose $\left(\mathrm{mL} \mathrm{ha}^{-1}\right)$} \\
\hline & \multirow{2}{*}{ Control } & 100 & 200 & 300 \\
\hline & & \multicolumn{3}{|c|}{$\mathrm{pH}(\mathrm{m})$} \\
\hline Soil $^{1}$ & 0.99 & $1.08 \mathrm{a}$ & 1.10 & $1.09 \mathrm{a}$ \\
\hline Furrow ${ }^{2}$ & 0.99 & $1.00 \mathrm{~b}$ & 1.06 & $1.07 \mathrm{ab}$ \\
\hline Seed $^{3}$ & 0.99 & $1.08 \mathrm{a}$ & 1.06 & $1.01 \mathrm{~b}$ \\
\hline Plant $^{4}$ & 0.99 & $1.11 \mathrm{a}$ & 1.06 & $1.08 \mathrm{ab}$ \\
\hline
\end{tabular}

Means followed by the same letter in the columns do not differ statistically by Tukey test at 0.05 probability level;

${ }^{1} y=0.9912+0.0011 x-0.000003 x^{2}\left(R^{2}=0.99\right) ;{ }^{2} y=0.9830+0.0003 x\left(R^{2}=0.92\right)$ ${ }^{3} y=0.9947+0.00108 x-0.000004 x^{2}\left(R^{2}=0.92\right) ;{ }^{4} y=1.003+0.00095 x-0.000003 x^{2}$ $\left(R^{2}=0.57\right)$

Azospirillum strains, is one of the factors responsible for the stimulating effect observed on plant growth. As found in the present study, rice growth had hormonal effect when plants were inoculated, in relation to the control.

For 100-grain weight in the 2012/13 season, the control without inoculant showed higher value compared with the other doses of inoculant containing Azospirillum brasilense, fitting to a decreasing linear equation (Table 4). These results corroborate with the study of Goes (2012), who observed that, in the absence of bacteria, the 100-grain weight was higher than that of the treatment with inoculation, which was attributed by the author to the increase in vegetative area, which in turn can reduce 100 -grain weight.

For hectoliter mass and according to the observed means (Table 4), there was no significant difference between the treatments.

For grain yield, there was no difference between treatments in the first year; similarly, Banheza et al. (2012) also did not observe influence of the doses of 0,100, 200 and $400 \mathrm{~mL} \mathrm{ha}^{-1}$ of commercial inoculant applied in the seed on upland rice yield. Gitti et al. (2012), evaluating the effect of seed inoculation with A. brasilense with $200 \mathrm{~g}$ of inoculant for $25 \mathrm{~kg}$ of seeds, did not find influence on the yield of upland rice under sprinkler irrigation.

The data of the second agricultural year also did not indicate significant differences for the forms of application of the inoculant; however, for the doses, the data fitted to a quadratic equation. The maximum point occurred at the inoculant dose of $192 \mathrm{~mL} \mathrm{ha}^{-1}$, which corresponded to the estimated grain yield of $6,622 \mathrm{~kg} \mathrm{ha}^{-1}$; therefore, an increment of $9.47 \%$ in relation to the control. Thus, it is noted that the inoculation promoted

Table 4. Mean values of 100-grain weight (100GW), hectoliter mass (HM) and grain yield (GY) of upland rice as a function of doses and forms of application of inoculant containing Azospirillum brasilense during 2011/12 and 2012/13 season

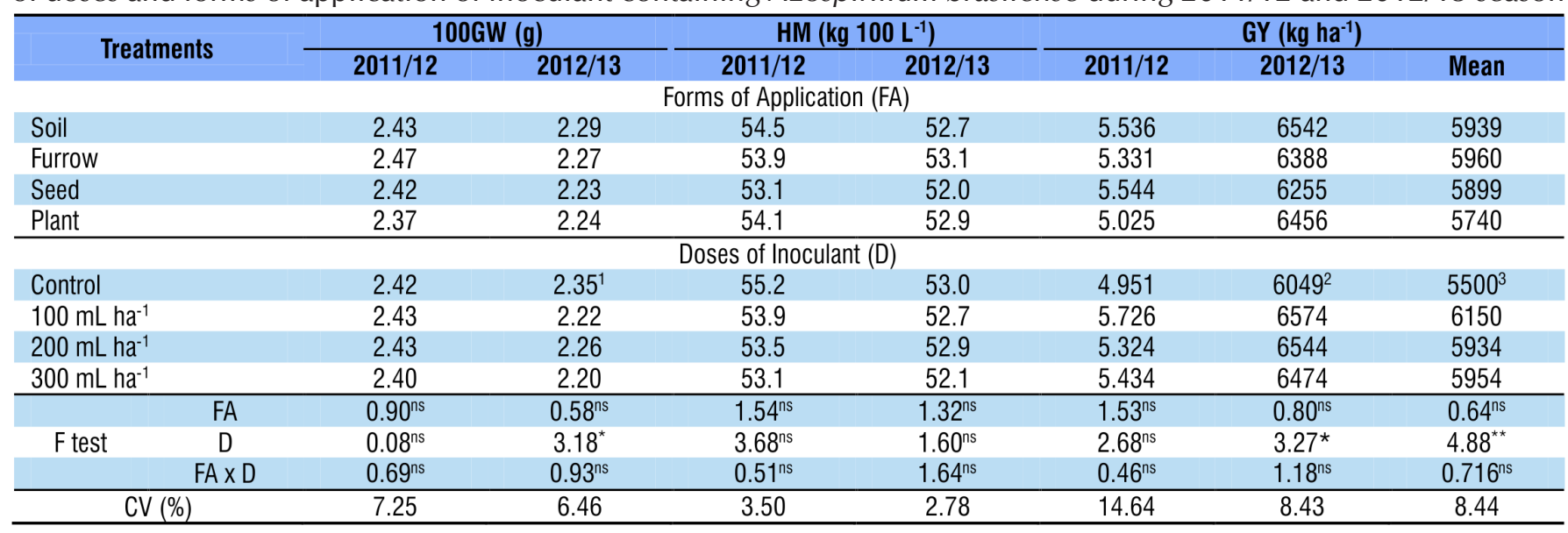

ns - not significant; ${ }^{*}$ - significant at 0.05 probability level. ${ }^{1} 2.317500-0.000388 \times\left(R^{2}=0.70\right) ;{ }^{2} 6074.8551+5.7041 x-0.01487 x^{2}\left(R^{2}=0.93\right) ;{ }^{35554.97}+5.87 x-0.01575 x^{2}$ 
greater increase in rice yield when performed close to the dose of $200 \mathrm{~mL} \mathrm{ha}^{-1}$, which can be an interesting technology for the rice producer.

The mean yield of both years increased with the application of $A$. brasilense, regardless of the form of application of the inoculant, and the doses fitted to a quadratic model with maximum point of $186 \mathrm{~mL} \mathrm{ha}^{-1}$, corresponding to an increment of $10.9 \%$ in relation to the control.

As occurred in this study, other studies developed under different conditions also reported yield gains with the inoculation of Azospirillum brasilense. Rodrigues et al. (2015) concluded that the inoculation with $200 \mathrm{~mL}$ of inoculant for $50 \mathrm{~kg}$ of seeds promotes increment of $22 \%$ in the grain yield of the cultivar IAC 202 under sprinkler irrigation in Selvíria-MS. Majumdar et al. (2007), evaluating the effect of Azospirillum brasilense inoculated in the seed in an experiment developed in India in soil with sandy loam texture, observed increase of $9.1 \%$ in the grain yield of upland rice. Ferreira et al. (2015) also observed positive response of the inoculation on the yield components, which can lead to an increment in the yield of the inoculated rice cultivars.

These benefits are due to the action of the bacteria through the process of biological $\mathrm{N}$ fixation and the promotion of plant growth, through the production of various vegetal hormones that result in greater growth and absorption of water and nutrients (Moreira et al., 2010), which may have increased the productive potential of the rice crop.

\section{Conclusions}

1. There is difference between the forms of application of inoculant containing Azospirillum brasilense on the grain yield of upland rice under sprinkler irrigation.

2. The inoculant containing Azospirillum brasilense promotes increment (10.9\%) in the yield of upland rice under sprinkler irrigation, when used at the dose of $200 \mathrm{~mL} \mathrm{ha}^{-1}$.

\section{Literature Cited}

Araújo, A. E. S.; Rossetto, C. A. V.; Baldani, V. L. D.; Baldani, J. I. Germinação e vigor de sementes de arroz inoculadas com bactérias diazostróficas. Ciência e Agrotecnologia, v.34, p.932939, 2010. http://dx.doi.org/10.1590/S1413-70542010000400019

Banheza, I. L. B.; Lavezo, A.; Banheza, I. B.; Kroetz, H. I.; Koga, P. S. Inoculação com Azospirillum brasilense e doses de nitrogênio na cultura de arroz de terras altas na região de Alta Floresta-MT. Revista de Ciências Agro-Ambientais, v.10, p.205-212, 2012.

Bottini, R.; Fulchieri, M.; Pearce, D.; Pharis, R. Identificação de giberelinas A1, A3, and iso-A3 em culturas com A. lipoferum. Plant Physiology, v.90, p.45-47, 1989. http://dx.doi.org/10.1104/ pp.90.1.45

Cantarella, H.; Furlani, P. R. Arroz de sequeiro. In: Raij, B. van; Cantarella, H.; Quaggio, J. A.; Furlani, A. M. C. (coord.). Recomendações de adubação e calagem para o Estado de São Paulo. 2.ed. Campinas: Instituto Agronômico \& Fundação IAC, 1996. p.48-49.

CONAB - Companhia Nacional de Abastecimento. Acompanhamento da safra brasileira de grãos. Décimo levantamento, safra 2015/16. Brasília: CONAB, v.3, n.10, 2016.
Elbeltagy, A.; Nishioka, K.; Sato, T.; Suzuki, H.; Ye, B.; Hamada, T.; Isawa, T.; Mitsui, H.; Minamisawa, K. Endophytic colonization and in plant nitrogen fixation by a Herbaspirillum sp. isolated from wild rice species. Applied and Environmental Microbiology, v.67, p.5285-5293, 2001. http://dx.doi.org/10.1128/AEM.67.11.52855293.2001

Fageria, N. K.; Barbosa Filho, M. P. Nitrogen use efficiency in lowland rice genotypes. Communication Soil Science Plant Analysis, v.32, p.2079-2089, 2001. http://dx.doi.org/10.1081/ CSS -120000270

Fageria, N. K.; Stone, L. F. Manejo do nitrogênio. In: Fageria, N. K.; Stone, L. F.; Santos, A. B. dos (ed.). Manejo da fertilidade do solo para o arroz irrigado. Santo Antônio de Goiás: Embrapa Arroz e Feijão, 2003. p.51-94.

Ferreira, D. F. SISVAR: Um sistema computacional de análise estatística. Ciência e Agrotecnologia, v.35, p.1039-1042, 2011.

Ferreira, E. P. B.; Castro, A. P.; Martin-Didonet, C. C. G.; Fageria, N. K. Desempenho agronômico de cultivares de arroz de terras altas inoculados com Azospirillum brasilense de acordo com o genótipo da planta. Communications in Soil Science and Plant Analysis, v.46, p.1751-1762, 2015. http://dx.doi.org/10.1080/0 0103624.2015 .1043456

Gitti, D. C.; Arf, O.; Portugal, J. R.; Corsini, D. C. D. C.; Rodrigues, R. A. F.; Kaneko, F. H. Coberturas vegetais, doses de nitrogênio e inoculação de sementes com Azospirillum brasilense em arroz de terras altas no sistema plantio direto. Bragantia, v.71, p.509-517, 2012. http://dx.doi.org/10.1590/S000687052013005000002

Goes, R. J. Inoculação de sementes com Azospirillum brasilense e doses de $\mathrm{N}$ mineral em arroz de terras altas irrigado por aspersão. Ilha Solteira: UNESP, 2012. 30p. Dissertação Mestrado

Guimarães, S. L.; Baldani, J. I.; Baldani, V. L. D.; Jacob Neto, J. Adição de molibdênio ao inoculante turfoso com bactérias diazotróficas usado em duas cultivares de arroz irrigado. Pesquisa Agropecuária Brasileira, v.42, p.393-398, 2007.

Hungria, M.; Campo, R. J.; Souza, E. M. S.; Pedrosa, F. O. Inoculation with selected strains of Azospirillum brasilense and A. lipoferum improves yields of maize and wheat in Brazil. Plant and Soil, v.331, p.413-425, 2010. http://dx.doi.org/10.1007/s11104-0090262-0

Majumdar, B.; Venkatesh, M. S.; Saha, R. Effect sf nitrogen, farmyard manure and non-symbiotic nitrogen-fixing bacteria on yield, nutrient uptake and soil fertility in upland rice (Oryza sativa). Indian Journal of Agricultural Sciences, v.77, p.335-339, 2007.

Malavolta, E.; Vitti, G. C.; Oliveira, S. A. Avaliação do estado nutricional das plantas: Princípios e aplicações. 2.ed. Piracicaba: Potafos, 1997. 319p.

Moreira, F. M. S.; Silva, K.; Nóbrega, R. S. A.; Carvalho, F. Bactérias diazotróficas associativas: Diversidade, ecologia e potencial de aplicações. Comunicata Scientiae, v.1, p.74-99, 2010.

Perrig, D.; Boiero, L.; Masciarelli, O.; Penna, C.; Cassán, F.; Luna, V. Plant growth promoting compounds produced by two agronomically important strains of Azospirillum brasilense, and their implications for inoculant formulation. Applied Microbiology and Biotechnology, v.75, p.1143-1150, 2007. http:// dx.doi.org/10.1007/s00253-007-0909-9 
Radwan, T. E. E.; Mohamed, Z. K.; Reis, V. M. Efeito da inoculação de Azospirillum e Herbaspirillum na produção de compostos indólicos em plântulas de milho e arroz. Pesquisa Agropecuária Brasileira, v.39, p.987-994, 2004. http://dx.doi.org/10.1590/S0100204X2004001000006

Raij, B. van; Andrade, J. C.; Cantarella, H.; Quaggio, J. A. Análise química para avaliação da fertilidade de solos tropicais. Campinas: Instituto Agronômico, 2001. 284p.

Rodrigues, M.; Arf, O.; Garcia, N. F. S.; Portugal, J. R.; Barbieri, M. K. F. Inoculação de sementes com Azospirillum brasilense e adubação nitrogenada em cultivares de arroz de terras altas irrigados por aspersão. Enciclopédia Biosfera, v.11, p.1234-1241, 2015.
Rodrigues, R. A. F.; Soratto, R. P.; Arf, O. Manejo de água em arroz de terras altas no sistema de plantio direto usando o tanque de Classe A. Engenharia Agrícola, v.24, p.546-556, 2004. http:// dx.doi.org/10.1590/S0100-69162004000300007

Santos, H. G.; Jacomine, P. K. T.; Oliveira, V. A.; Lumbreras, J. F.; Coelho, M. R.; Almeida, J. A.; Cunha, T. J. F.; Oliveira, J. B. Sistema brasileiro de classificação de solos. 3.ed. Brasília: EMBRAPA, 2013.353p.

Zamberlan, C. O.; Sonaglio, C. M. A produção orizícola brasileira a partir da década de 1990: Evolução e perspectivas econômicas. Qualit@s,v.1,p.1-15, 2011. 